\title{
THE PLACE OF OATS IN THE COELIAC DIET
}

\author{
BY \\ A. LINDSAY C. MOULTON \\ From the Department of Paediatrics and Child Health, University of Birmingham, and Birmingham Children's Hospital
}

(RECEIVED FOR PUBLICATION JUNE 21, 1958)

Since the discovery by Dicke (1950) that remarkable benefit followed the withdrawal of wheat and rye from the diet of the coeliac child, much work has been done on the significance of these and other foodstuffs in the coeliac syndrome. Few of these studies, however, involved oats, a food containing a prolamin similar to the gliadin of wheat which was proved to be injurious by van de Kamer, Weijers and Dicke (1953).

In 1955, van de Kamer and Weijers suggested that the effects of various foodstuffs on the coeliac patient are related to their amide:non-amide nitrogen ratios and they compiled a list of foods arranged according to this ratio. In many respects their series agrees with the known effects of the foods in coeliac disease. Oats and oatflakes are of interest as they are placed on the margin between the harmful and non-harmful foods.

Previous workers on oats, Dicke, Weijers and van de Kamer (1953), and van de Kamer et al. (1953), who fed the same child $140 \mathrm{~g}$. oatmeal per day, and Hansted (1955), who gave one child 150 g. oatmeal per day, claim that such large intakes have some harmful effect. However, in another patient, $75 \mathrm{~g}$. oatmeal per day produced only a slight increase in fat excretion (Hansted, 1955). The effect of still smaller amounts on two groups of three patients each was investigated by Sheldon (1955). The first group received $2 \mathrm{oz}$. (56 g.) oatmeal per day and the second 1 oz. ( $28 \mathrm{~g}$.). Despite the short duration of his experiments, he concludes that oatmeal, at these more normal levels, has no ill effect on coeliac children. Frazer (1956) reports that his team found no deleterious effect of oats, but details are not given.

Hansted (1956a) suggests that either a high intake of oats for a short time or a small intake over an extended period is necessary to cause an increase equivalent to that produced by wheat in the fat excretion of coeliac children. Attention has been focused on this suggestion in the present investigation. Four cases only have been studied as the continuous fat balances necessary to demonstrate any resulting slight upward trend in fat excretion are very time consuming. A further problem is that high intakes of oats are not easily maintained, as the child becomes tired of the flavour and overwhelmed by the bulk of the food.

The possibility of using oat protein itself was explored but, although several methods of preparation were attempted, considerable difficulties were encountered. Oats do not yield a gluten, although they contain a gliadin and a glutelin similar to those found in the gluten of wheat. Thus preparation of protein by merely washing gluten free from starch is not feasible. No concentrated oats in the form of protein have been used in the present investigation, though dry separation of oat protein particles by means of a micronizer would appear to be the most suitable method of preparation. If in future experiments large quantities of oats prove too much for a child's appetite, replacement with equivalent amounts of this oat protein could be attempted.

\section{Methods and Patients}

Continuous fat balance studies over relatively long periods were carried out, fat being estimated daily in the stools by the method of van de Kamer, Huinink and Weijers (1949). Any uneaten food was weighed, analysed for fat and its oat content calculated. Threeday sliding means of the faecal fat excretion and the percentage fat absorption were calculated. In addition, seven-day means of fat intake, fat excretion, percentage fat absorption and oat intake were obtained as these figures show more clearly the general trend of the results. Both for this reason and because of the rather lengthy results in certain cases, only the seven-day means have been charted (Figs. 1-4).

Four coeliac children, diagnosed according to the criteria described by Smellie (1956), were fed on a diet which was gluten-free apart from the content of Three Bears Oats (quick porridge oat flakes: fat content $6.3 \%$; amide: non-amide nitrogen ratio=14). As the nitrogen content of oats varies considerably (Moir, 1946), one batch of oatflakes was used throughout. The quantities of oatflakes fed were $46,70,163$ and $169 \mathrm{~g}$. per day, the lengths of the trials being 45, 96, 22 and 23 days respectively. 


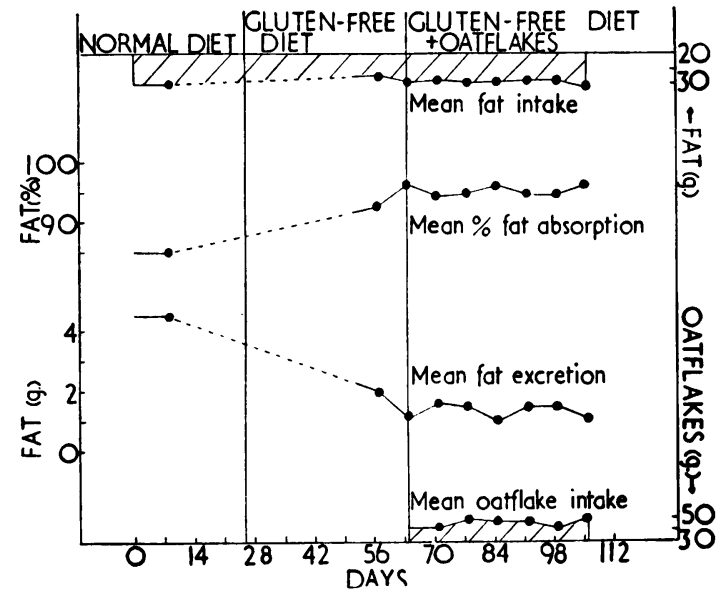

FIG. 1.-Seven-day means of fat excretion and percentage fat absorption in Case 1.-Average oatflake intake $46 \mathrm{~g}$. per day.

\section{Results}

The results are presented in Figs. 1 to 4 and Tables 1 and 2 . In Table 1 are shown the average quantities of fat excreted during normal diets containing gluten, together with the low values to which the patients' faecal fat excretions fell when they were given gluten-free diets. Consumptions of small quantities of oatflakes (46 and $70 \mathrm{~g}$. per day), added to the previous gluten-free diet, caused no rise in fat excretion, but increases up to seven-day mean

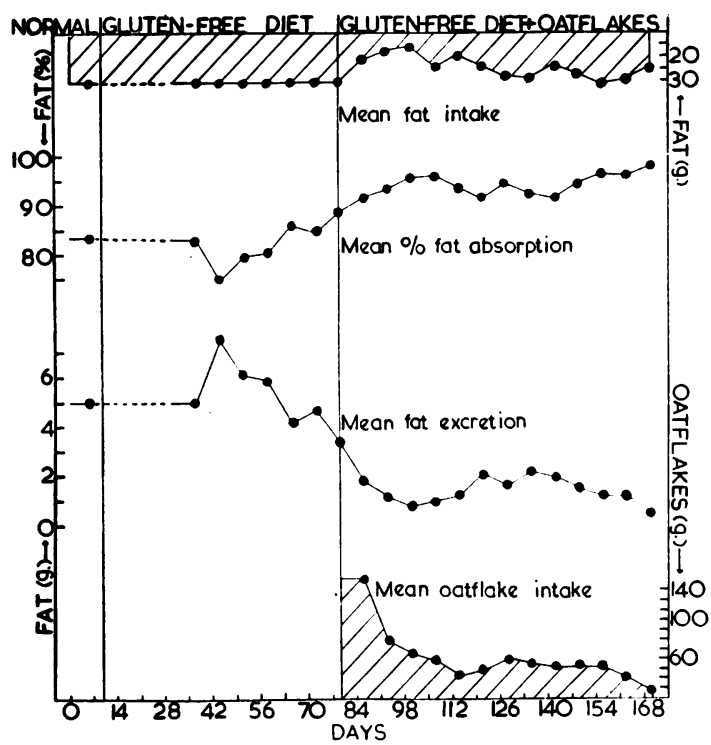

Fig. 2.-Seven-day means of fat excretion and percentage fat absorption in Case 2. Average oatflake intake 70 g. per day.

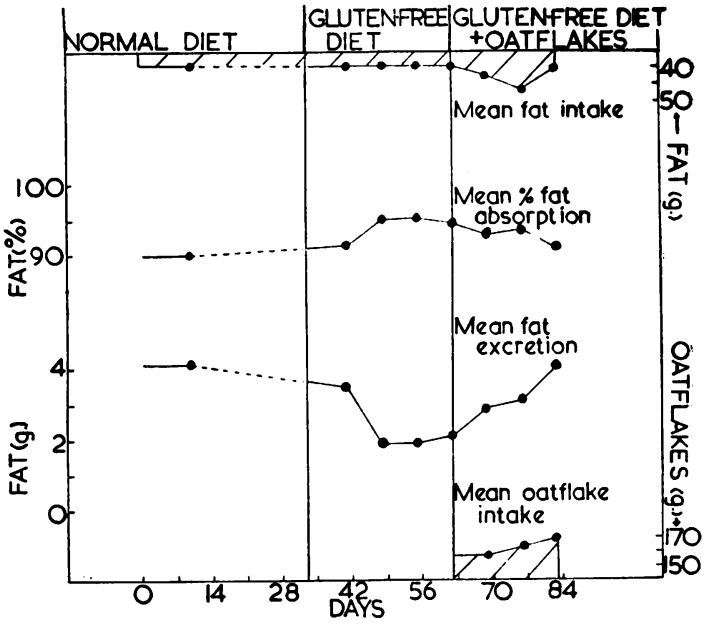

FIG. 3.-Seven-day means of fat excretion and percentage fat absorption in Case 3. Average oatflake intake $163 \mathrm{~g}$. per day.

values of 4.0 and $4 \cdot 1 \mathrm{~g}$. fat per day during the trial period resulted when 169 and $163 \mathrm{~g}$. per day were eaten.

\section{Discussion}

Barley (Hansted, 1956b), wheat and rye (Dicke, 1950) are considered harmful to coeliac children; in the case of wheat, the prolamin or gliadin is thought to be responsible (van de Kamer et al.,

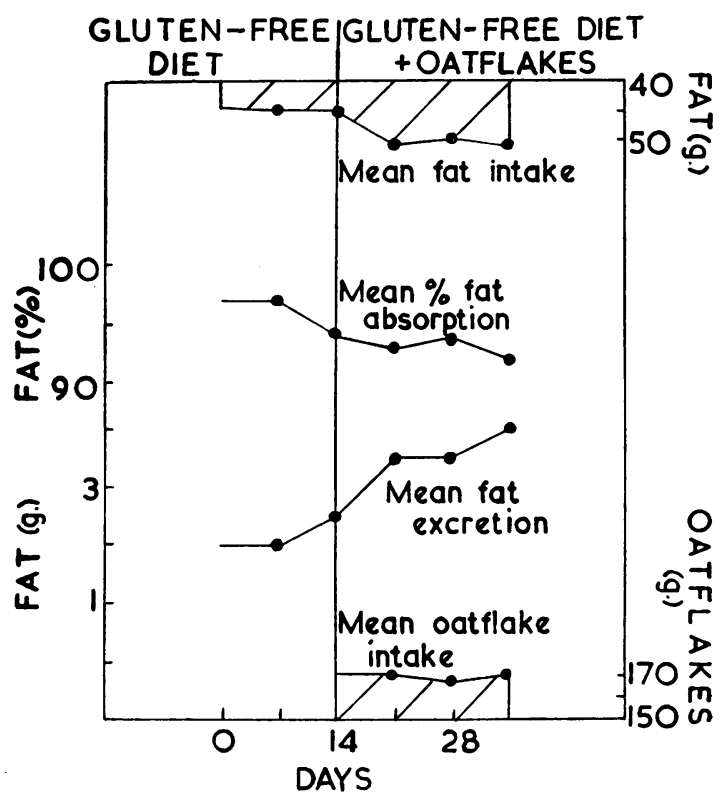

Fig. 4. - Seven-day means of fat excretion and percentage fat absorption in Case 4. Average oatflake intake $169 \mathrm{~g}$. per day. 
TABLE 1

CASE HISTORIES

\begin{tabular}{|c|c|c|c|c|c|c|c|c|c|c|c|c|}
\hline \multirow[b]{2}{*}{ Patient } & \multirow[b]{2}{*}{$\begin{array}{l}\text { Age } \\
\text { (yr.) }\end{array}$} & \multirow[b]{2}{*}{ Presenting Symptoms } & \multicolumn{3}{|c|}{$\begin{array}{c}\text { Normal Diet } \\
\text { (before treatment) }\end{array}$} & \multicolumn{3}{|c|}{ Gluten-free Diet } & \multicolumn{4}{|c|}{ Gluten-free Diet + Oatflakes } \\
\hline & & & $\begin{array}{c}\text { Days } \\
\text { (averaged) }\end{array}$ & $\underset{(\mathrm{g} / \mathrm{d} .)}{\mathrm{M}}$ & $\begin{array}{l}\text { n Fat } \\
\text { Absorp. } \\
\text { (\%/d.) }\end{array}$ & $\underset{\text { (days) }}{\text { Duration }}$ & $\underset{\text { (g./d.) }}{\text { Excr. }}$ & $\begin{array}{l}\text { Absorp. } \\
\text { (\%/d.) }\end{array}$ & $\begin{array}{c}\text { Mean } \\
\text { Oatflake } \\
\text { Intake } \\
\text { (g./d.) }\end{array}$ & $\begin{array}{c}\text { Duration } \\
\text { (days) }\end{array}$ & $\underset{\text { (g./d.) }}{\text { Excr. }}$ & $\begin{array}{l}\text { at } \\
(\% / \text { d. })\end{array}$ \\
\hline 1 & $29 / 12$ & $\begin{array}{l}\text { Anaemic. Pale and } \\
\text { easily tired since } \\
\text { birth }\end{array}$ & 8 & $4 \cdot 5$ & 85 & 39 & $\Varangle 1 \cdot 1$ & $\not>96.3$ & 46 & 45 & $\ngtr 1.6$ & $-94 \cdot 5$ \\
\hline 2 & $15 / 12$ & $\begin{array}{l}\text { Stools frequent and } \\
\text { bulky for } 1 \mathrm{~m} \text {. before } \\
\text { admission. Distend- } \\
\text { ed abdomen. Weight } \\
\text { loss }\end{array}$ & 6 & $5 \cdot 0$ & $83 \cdot 5$ & 71 & $\nless 3.4 \dagger$ & $\ngtr 88 \cdot 7 \dagger$ & 70 & 96 & $\not 2 \cdot 2$ & $\Varangle 92.3$ \\
\hline 3 & 10 & $\begin{array}{l}\text { Thin, pale child. Re- } \\
\text { current diarrhoea } \\
\text { over previous } 4 \text { yr. }\end{array}$ & 10 & $4 \cdot 1$ & 90 & 30 & $\nless 2.0$ & $\ngtr 95$ & 163 & 22 & $\not 4 \cdot 1$ & $\Varangle 91$ \\
\hline 4 & 11 & $\begin{array}{l}\text { Diarrhoea attacks } \\
\text { since } 7 \mathrm{~m} \text {. old. Diag- } \\
\text { nosed as coeliac at } \\
18 \mathrm{~m} \text {. On home } \\
\text { gluten-free diet since } \\
3 \frac{1}{2} \mathrm{yr} \text {. }\end{array}$ & 5 & $5 \cdot 0$ & $? \ddagger$ & $19 \S$ & $2 \cdot 2$ & $95 \cdot 1$ & 169 & 23 & $\ngtr 4.0$ & $\nless 92$ \\
\hline
\end{tabular}

- Seven-day means.

$\dagger$ Although the child was not fully equilibrated on a gluten-free diet at this stage, oatfiakes were given on the assumption that the fat excretion would not rise if they were harmless.

₹ecord lost.

$\S$ Strict gluten-free diet in hospital, as opposed to gluten-free diet at home.

1953). It is therefore of interest that, in a list of the quantities of prolamins in the dry grains of several cereals, in which the total protein contents are approximately equal, Brohult and Sandegren (1954) give wheat, rye and barley prolamins as $40-50 \%, 30-50 \%$ and $35-45 \%$ respectively of total protein, and oats as only $10-15 \%$. That of rice is low. Thus, large quantities of prolamin are found in all three of the harmful cereals mentioned above, smaller amounts in oats, possibly correlated with their less detrimental effect, and very little in rice which can be safely eaten by coeliac children.

The prolamin content of maize, however, is stated to be $50-55 \%$ of the total protein. If all cereals containing large quantities of prolamin are to be considered detrimental to the coeliac patient this high value for maize prolamin requires consideration. It is approximately equal to the figures of

TABLE 2

COMPARISON OF PUBLISHED RESULTS WITH PRESENT FINDINGS

\begin{tabular}{|c|c|c|c|c|c|c|c|}
\hline & \multirow{2}{*}{$\begin{array}{l}\text { Age } \\
\text { (yr.) }\end{array}$} & \multirow{2}{*}{$\begin{array}{l}\text { Oat Intake } \\
\text { (g./d.) }\end{array}$} & \multirow{2}{*}{$\begin{array}{c}\text { Duration of } \\
\text { Oat } \\
\text { Supplement } \\
\text { (days) }\end{array}$} & \multicolumn{2}{|c|}{ Gluten-free Diet } & \multicolumn{2}{|c|}{ Gluten-free Diet + Oats } \\
\hline & & & & $\begin{array}{l}\text { Fat Excr. } \\
\text { (g./d.) }\end{array}$ & $\begin{array}{l}\text { Fat Absorp. } \\
(\% / d .)\end{array}$ & $\begin{array}{l}\text { Fat Excr. } \\
\text { (g./d.) }\end{array}$ & $\begin{array}{l}\text { Fat Absorp. } \\
(\% / \text { d.) }\end{array}$ \\
\hline $\begin{array}{l}\text { Dicke et al. (1953) } \\
\text { Above authors; also }\end{array}$ & 9 & & 3-4 w. & $4 \cdot 3^{*}$ & $91 \cdot 3^{*}$ & & $85 \cdot 3^{*}$ \\
\hline $\begin{array}{l}\text { van de Kamer et al. (1953) } \\
\text { Hansted (1955) }\end{array}$ & & $\begin{array}{l}140 \\
150\end{array}$ & $\begin{array}{r}52 \dagger \\
1 \mathrm{~m} . \dagger\end{array}$ & $2 \cdot 4$ & $\begin{array}{l}95 \cdot 5 \\
89.9 \ddagger\end{array}$ & $5 \cdot 2$ & $89 \cdot 6$ \\
\hline $\begin{array}{lll}\text { Sheldon (1955) } & \cdots & \cdots\end{array}$ & $\begin{array}{rl} & 4 \\
1 & 9 / 12 \\
5 & 10 / 12 \\
7 & 2 / 12 \\
4 & 3 / 12 \\
4 & 2 / 12 \\
10 & 4 / 12 \\
\end{array}$ & $\begin{array}{l}13 \\
28 \\
28 \\
28 \\
56 \\
56 \\
56 \\
\end{array}$ & $\begin{array}{c}18 \\
18 \\
22 \\
34 \\
15 \\
15 \\
22\end{array}$ & $\begin{array}{l}\text { I.47 } \\
\text { 二 } \\
= \\
=\end{array}$ & $\begin{array}{l}95 \cdot 9 \ddagger \\
\overline{87} \\
93 \\
95 \cdot 5 \\
91 \\
91\end{array}$ & $\begin{array}{l}2 \cdot 37 \\
= \\
= \\
=\end{array}$ & $\begin{array}{c}93.67 \\
93 \\
87 \\
93 \\
97 \\
88 \\
89 \\
\end{array}$ \\
\hline Present Study $\quad \ldots$ & $\begin{array}{r}10 \\
11 \\
1 \\
3\end{array} 6 / 12$ & $\begin{array}{r}163 \\
169 \\
70 \\
46\end{array}$ & $\begin{array}{l}22 \\
23 \\
96 \\
45\end{array}$ & $\begin{array}{l}2 \cdot 2 \\
2 \cdot 3 \\
5 \cdot 2 \\
1 \cdot 5\end{array}$ & $\begin{array}{l}94 \cdot 5 \\
95 \cdot 1 \\
82 \cdot 7 \\
94 \cdot 7\end{array}$ & $\begin{array}{l}3 \cdot 5 \\
3 \cdot 7 \\
1 \cdot 4 \\
1 \cdot 3\end{array}$ & $\begin{array}{l}91 \cdot 9 \\
93 \\
94 \cdot 2 \\
95 \cdot 5\end{array}$ \\
\hline
\end{tabular}

* These values are high as they were obtained just after the patient was changed from a normal diet for the first time. The second set of figures probably indicates the patient's true reactions.

+ Approximately.

$\ddagger$ Hansted has presented these data in the form of graphs only; approximations from these are given. 
Hansen, Brimhall and Sprague (1946), but wide ranges for the prolamin content of maize, $25-60 \%$ and $28-57 \%$ of total protein, are given by Doty, Bergdoll, Nash and Brunson (1946) and Showalter and Carr (1922) respectively, as the prolamin content of the maize grain rises with increasing maturity (Zeleny, 1935) and nitrogen content (Showalter and Carr, 1922; Hansen, Brimhall and Sprague, 1946). Despite this variation, if maize prolamin is similar in structure and action to that of wheat, it is reasonable to suppose that maize would be detrimental to coeliac children. Hansted (1956b), without giving details, claims that maize, as such, is well tolerated, but in the majority of trials including those of van de Kamer et al. (1953), Dicke et al. (1953) and Hansted (1955), the only forms of corn (maize) investigated were cornstarch, or cornflour which consists almost exclusively of cornstarch (Ford, 1946). Thus although cornstarch like wheatstarch is harmless to the coeliac patient, the maize prolamin, zein, does not appear to have been tested and may, therefore, be injurious both by itself and in the form of the maize grain.

When placed in order of magnitude, the various cereal prolamin contents, quoted above, correspond to a series of foods similar, apart from maize, to that given by van de Kamer and Weijers (1955). In this latter series, rice, maize, oatflakes, oats, barley flour, rye flour, wheat flour and gliadin, among other foods, are arranged according to their amide:nonamide nitrogen ratios which are $11,11,12,13,14$, 17,23 and 30 respectively. Thus, without suggesting a precise quantitative relationship between either of these sets of figures and the effect of the foods on the coeliac, it is obvious that, should the prolamin be responsible for the deleterious effect, much greater quantities of oats than wheat could be eaten with safety by coeliac children.

If large quantities of oats or oatflakes are likely to have harmful effects, the three levels of intake fed in the present experiments ought to result in a progressive increase in fat excretion Such an increase is shown in Table 2 in which the lowest level of oatflake feeding ( $46 \mathrm{~g}$. per day) corresponds to a fat excretion of $1.3 \mathrm{~g}$. per day and the highest (169 g. oatflakes per day) to $3 \cdot 7 \mathrm{~g}$. faecal fat per day. The fat excretion during the $70 \mathrm{~g}$. oatflake diet, though slightly higher, resembles that corresponding to the $46 \mathrm{~g}$. oatflake diet. It should be noted that in Table 2 the results of the present study are given in the form of averages of all the fat excretion and percentage fat absorption values obtained during each particular dietary period, without allowance being made in the calculations for the children's fat excretions to become equilibrated on each new diet.
Since the child having $70 \mathrm{~g}$. oatflakes per day was not fully equilibrated on a gluten-free diet, an average of all available figures gives a falsely high fat excretion. Reference to Fig. 2 shows that her final fat excretion on a gluten-free diet was much lower than $5 \cdot 0 \mathrm{~g}$. per day.

In Table 2, the results of other workers are given for comparison. They seem to follow the same general trend, although the varying lengths of the studies complicate their appraisal. The first three sets of figures are the results of feeding large quantities of oatmeal over long periods. They demonstrate a rise in fat excretion to values just above the upper limits of normal. In the present investigation, the figures obtained during the feeding of even greater amounts of oatflakes have not reached such high levels. Possibly if we could have persuaded our children to eat large quantities of oatflakes for a longer period, their excretion of fat would have risen even further. Indeed, the mean values for the third seven-day periods had reached $4 \cdot 1$ and $4.0 \mathrm{~g}$. per day on 163 and $169 \mathrm{~g}$. oatflakes respectively (Figs. 3 and 4). The fact that oatflakes were fed in the present experiments, whereas oatmeal was investigated by the other authors, may have some significance, for according to the list of amide-nonamide nitrogen ratios of van de Kamer and Weijers (1955) oatflakes with a ratio of 12 ought to be slightly less harmful than oatmeal at 13 . However, the ratio in our particular batch of Three Bears Oats was 14. Variations in nitrogen content, etc., may frequently be caused by changes in weather and soil conditions. The value 14 still does not approach wheat flour at 23 or wheat gliadin at 30 .

Our results give some indication of the intake of oatflakes which can be given to the coeliac with safety. Thus, one patient receiving $70 \mathrm{~g}$. oatflakes per day for 90 days and another receiving $46 \mathrm{~g}$. per day for 45 days showed no increase in fat excretion. Hansted (1955) found that a child fed on $75 \mathrm{~g}$. oatmeal per day for one month did show a slight increase in fat excretion (Table 2). This might appear to conflict with our findings but the increase, noted by Hansted, is well within normal limits. Thus, it seems that 1-2 oz. (28-56 g.) oatflakes per day may be given to the coeliac with safety, a conclusion which is supported by Sheldon's (1955) shorter studies when feeding $1 \mathrm{oz}$. (28 g.) oatmeal per day (Table 2). Two of his three cases who received 2 oz. ( 56 g.) oatmeal per day did suffer a slight deleterious effect, although he does not consider the change in fat absorption of importance. This view is probably justified as, in England at least, oats are unlikely to be eaten every day, though a trial of a foodstuff suspected of having only a 
slight effect should be continued for a considerable time, especially when only small amounts are eaten. The increase in fat excretion, produced by the largest intakes which have been given, are still within normal limits and, in our experience, it was almost impossible for the patients to consume even this bulk of oats daily.

\section{Summary}

The effects of giving 46, 70, 163 and $169 \mathrm{~g}$. oatflakes per day to four coeliac children for 45,96 , 22 and 23 days respectively have been studied and the results compared with those of other workers. It is concluded that, at least in some coeliac patients, amounts up to $2 \mathrm{oz}$. $(56 \mathrm{~g}$.) oatflakes per day may be fed without ill effect. Even the highest quantities of oatflakes given (169 g. per day for three weeks, an amount almost impossible to consume) only produced an increase in faecal fat excretion up to the verge of normal limits.

I would like to express my gratitude to Professor J. M. Smellie, Mr. H. B. Salt and Dr. O. H. Wolff for their interest and valuable criticism, to Miss J. E. Tilley for skilful management of the oatflake diets, to the nursing staff of the Birmingham Children's Hospital for their unfailing co-operation and to J. and J. Colman,
Ltd., for the gift of Three Bears Oats used throughout the investigation.

My thanks are also due to Dr. N. Blakebrough, Department of Chemical Engineering, Birmingham University and the Scottish Co-operative Wholesale Society Cereal Laboratory, Glasgow, for helpful advice on the preparation of oat protein and to Reckitt \& Colman, Ltd., Norwich, A. \& R. Scott, Ltd., Edinburgh, and Henry Simon, Ltd., Stockport, for practical aid in this problem.

\section{REFERENCES}

Brohult, S. and Sandegren, E. (1954). In The Proteins, ed. G. Neurath and K. Bailey, Vol. 2, part A, p. 487. New York.

Dicke, W. K. (1950). Coeliakie. M. D. Thesis. Utrecht.

-, Weijers, H. A. and Kamer, J. H. van de (1953). Acta paediat. (Uppsala), 42, 34.

Doty, D. M., Bergdoll, M. S., Nash, H. A. and Brunson, A. M. (1946). Cereal Chem. 23, 199

Ford, W. P. (1946).' In' The Nation's Food, ed. A. L. Bacharach and T. Rendle, p. 196. London.

Frazer, A. C. (1956). Proc. roy. Soc. Med., 49, 1009.

Hansen, D. W., Brimhall, B. and Sprague, G. F. (1946). Cereal Chem., $23,329$.

Hansted, C. (1955). Ugeskr. Laeg., 117, 481.

- (1956a). Personal communication.

(1956b). 8th International Congress of Paediatrics, exhibi-

tion 137. Copenhagen.
Kamer, J. H. van de, Huinink, H. ten Bokkel and Weijers, H. A. (1949). J. biol. Chem., 177, 347. and Weijers, H. A. (1955). Acta paediat. (Uppsala), 44, 465.

- and Dicke, W. K. (1953). Ibid., 42, 223.

Moir, H. C. (1946). In The Nation's Food, ed. A. L. Bacharach and T. Tendle, p. 205. London.

Sheldon, W. (1955). Lancet, 2, 1097.

Sheldon, W. (1955). Lancet, 2,' (1097.), 10, 279.

Showalter, M. F. and Carr. R. H. (1922). J. Amer. chem. Soc., 44 2019.

Zeleny, L. (1935). Cereal Chem., 12, 536. 